Book Review

\title{
In Search for Four Roads to Regionalism
}

Monika Kokstaite ${ }^{1,2}$

${ }^{1}$ Institute for European Studies, Vrije Universiteit Brussel, Pleinlaan 5, 1050 Brussels, Belgium;

E-Mail: monika.kokstaite@vub.ac.be

2 IMT Institute for Advanced Studies Lucca, Piazza S. Ponziano 6, 55100 Lucca, Italy

\section{How to Cite this Article}

Kokstaite, M. (2014). In Search for Four Roads to Regionalism. Politics and Governance, 2(1), 45-46.

\section{Copyrights}

(C) 2014 by the author; licensee Cogitatio (Lisbon, Portugal). This article is licensed under a Creative Commons Attribution 4.0 International License (CC BY).

\section{Published by:}

\section{COGITATIO}

www.cogitatiopress.com

\section{About the Journal}

Politics and Governance is an innovative new offering to the world of online publishing in the Political Sciences. An internationally peer-reviewed open access journal, Politics and Governance publishes significant, cutting-edge and multidisciplinary research drawn from all areas of Political Science.

www.cogitatiopress.com/politicsandgovernance

\section{Editors-in-Chief}

Professor Andrej J. Zwitter, Faculty of Law, University of Groningen, The Netherlands

Professor Amelia Hadfield, Department of Psychology, Politics and Sociology, Canterbury Christ Church University, UK

\section{Managing Editor}

Mr. António Vieira, Politics and Governance, Cogitatio Press, Portugal 


\title{
Book Review
}

\section{In Search for Four Roads to Regionalism}

\author{
Monika Kokstaite ${ }^{1,2}$ \\ ${ }^{1}$ Institute for European Studies, Vrije Universiteit Brussel, Pleinlaan 5, 1050 Brussels, Belgium; \\ E-Mail: monika.kokstaite@vub.ac.be \\ ${ }^{2}$ IMT Institute for Advanced Studies Lucca, Piazza S. Ponziano 6, 55100 Lucca, Italy
}

Submitted: 2 April 2014 | Published: 14 April 2014

\begin{abstract}
Book Review: Roads to Regionalism: Genesis, Design, and Effects of Regional Organizations. By Tanja A. Börzel, Lukas Goltermann, Mathis Lohaus and Kai Striebinger (Eds.). Burlington, UK: Ashgate, 2012, 294 pp.; ISBN: 978-1-4094-3464-1.
\end{abstract}

\section{Keywords}

design; genesis; regional organizations; regionalism

\section{Issue}

This book review is part of a regular issue of Politics and Governance, edited by Professor Andrej J. Zwitter (University of Groningen, The Netherlands) and Professor Amelia Hadfield (Canterbury Christ Church University, UK).

(C) 2014 by the author; licensee Cogitatio (Lisbon, Portugal). This article is licensed under a Creative Commons Attribution 4.0 International License (CC BY).

During the past few decades, the proliferation of regional organizations has generated a tremendous surge in regionalism studies. Recently published book Roads to Regionalism: Genesis, Design, and Effects of Regional Organizations, edited by Tanja A. Börzel, Lukas Goltermann, Mathis Lohaus and Kai Striebinger, presents an eclectic volume of non-European regionalism insights into academic debate. The book aims at four questions' framework-four distinct perspectives, or so-called 'roads', to study regionalism. In brief, from the authors' perspective, the analysis of genesis (why to set up, join or leave regional organization), institutional design (how institutions are created), domestic factors (how state's behavior affects regional organization) and effects (what is the impact of regional organization) allows grasping multiple dimensions of the compound nature of regionalism. This young scholars' volume is also organized around these four 'roads', mapping development patterns of regional organizations' (ROs) outside Europe. Chapter by chapter draws a sound picture of mostly undiscovered issues and features of ROs worldwide, mainly of ASEAN, MERCOSUR, NAFTA and ECOWAS.

The first 'road' maps the way of the creation of ROs and their development and growth worldwide. Three different cases dwell on regionalism initiatives in post-
Soviet Eurasia, South-East Asia and Latin America, revealing the reasons for establishing and/or joining RO, ways of integration and their results. The second question of institutional design is addressed by exploring the differences and similarities between ASEAN and NAFTA, and between ECOWAS and the Arab League. The answers to a question "why?" are complemented by the explorations of possible answers to "how?". The third block of chapters contributes to the discussion of the importance and the effects of state factors and behavior for regionalism, in particular exploring state's capacity and democratization effects in ROs in East Asia and Africa. Subsequently, the debate of effects is reversed, and the collection of the case studies examines ROs' impact and the effects on Member States (MS) in MERCOSUR, ASEAN and NAFTA.

The book's strengths stem from its four questions, theoretical eclecticism and a variety of ROs' cases analyzed. Research gaps in regionalism studies, indicated by Mansfield and Solingen (2010), like the necessity of understanding the direction of regionalisms and their autonomies in globalization, the role of hegemon, and the state and non-state actors are adequately covered in the Roads to Regionalism. In fact, the volume's thesis of "genesis, design and effects" completely reflects their call for the analysis of sources, forms and conse- 
quences. Some chapters provide insights into the effects of ROs, regarding human rights, accountability, democracy and transparency; while the reversed impact is analyzed in remaining part of the book. Correspondingly, Roads to Regionalism fills the gap of nonEuropean regionalism studies. On top of that, the linkages between political/security regionalism and economic regionalism are also analyzed and explained, for instance post-Soviet space, East Asia and other regions. In a nutshell, the book provides extensive explorations of ROs worldwide, like ASEAN, NAFTA, and MERCOSUR. The volume gives quite a broad and wide picture of the different kinds of regionalisms and their common ground.

However, several remarks should be made regarding weak sides of the book. As much as it seems theoretically eclectic volume from the first glance, Roads to Regionalism does not provide a sufficient combination and integration of qualitative and quantitative methods in the case studies. Although, quantitative methods or their combination with qualitative ones would have helped answering important questions more extensively. In addition, the only application of statistical analysis is slightly unconvincing: it is unclear what exact statistical methods were used to reveal the trends, what kind of relationship was modeled, and how missing data was interpreted in the study. Simultaneously, it is apparent the lack of referencing to more than one political economy theory (in this case Mattli's work), and their explanations of regional cooperation, as well as New Institutional Economics School's findings regarding functioning of institutions. Moreover, there is some bias in example of European integration. Regionalism per se is defined as a state-led project, whereas simultaneously authors look for the evidence of re- gionalization (market integration) like in the EU, even though, as Breslin and Higgott (2010) show that market integration is not necessarily a result of policies. Likewise, the question remains why is the comparison with the EU introduced only in some cases, if in fact there are more similarities than differences. One should not be surprised to discover how many similarities to the EU emerge, when old regionalism framework is applied for so-called new regionalism cases. To sum up, more combination of methods and reference to other literature would have made this volume even stronger handbook for interested in regionalism.

To conclude, as editors introduced and summarized, this volume shows not only the emergence of regionalism as a field of study, but also the importance of analyzing regionalism processes in other parts of the world. The goal of the book is ambitious and one will find new data exploration and many ideas and prospects for future research. A reader might feel discontented with some mismatches or ambiguous reasoning, like the statement about ECOWAS delegating more political authority to ROs than the EU MS (p. 260), or about powerful states' interests and benefits, for eg., Nigeria (p. 259) in the case of using RO for its own purposes. Someone might also find himself losing the point or skipping some parts in the text due to sporadically very long sentences or paragraphs. Nonetheless, interested in regionalism readers will find the volume helpful and inspiring. Roads to Regionalism paves the way for future regionalism studies, pioneers by contributing to the field with the analysis and presentation of multiplicity and complexity of ROs worldwide, and reassures the importance of three different aspects of ROs - genesis, design and multi-sided effects.

\section{About the Author}

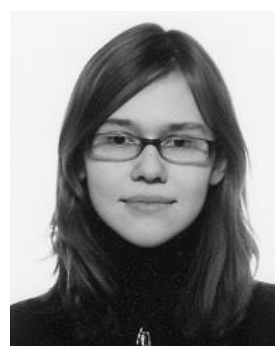

\section{Monika Kokstaite}

Monika Kokstaite will be a Visiting Researcher at the Institute for European Studies until November 2014. She is a PhD Candidate in Institutions, Politics and Policies at IMT Lucca, Italy. She is writing her $\mathrm{PhD}$ thesis on EU economic security policies and their effects. She holds an MA in International Relations and European Studies from the Central European University in Budapest. Her research focuses on good governance, human security, globalisation, regionalism, democratisation and sustainable development. She worked as a journalist and policy analyst for several years. Moreover, she has organised conferences and workshops with German Cultural Foundations. 